\title{
The Comparison of Physical Education and Sports Lessons Applied in Education Systems of Turkey and Kosovo
}

\author{
Gülten Hergüner ${ }^{1, *}$, Ayşe Önal ${ }^{1}$, Milaim Berisha ${ }^{1}$, Menzure Sibel Yaman ${ }^{2}$ \\ ${ }^{1}$ Institute of Educational Sciences, Physical Education and Sports, Sakarya University, Turkey \\ ${ }^{2}$ Health Sciences Institute, Physical Education and Sports, Gazi University, Turkey \\ *Corresponding Author: herguner@sakarya.edu.tr
}

Copyright $\bigcirc 2016$ by authors, all rights reserved. Authors agree that this article remains permanently open access under the terms of the Creative Commons Attribution License 4.0 international License.

\begin{abstract}
This study was conducted in order to compare and determine the differences between the syllabuses, class hours, subject topics, contents and acquirements of Physical Education and Sports Lessons in primary, middle and high schools in Turkey and Kosovo. This is an international comparative education study in which the aim is to reveal the similarities and differences through the use of the descriptive and evaluative approach, which is generally used in comparative education studies. In the end of the examination, the programs related to Physical Education and Sports in Turkey were observed to be more extensive, multi optional and flexible, while in the case of activities, they were found to be more uncertain. The programs in Kosovo however, were noted as being open, orderly, clear and with a low amount of flexibility. While in the content in Turkey, attainments towards the cognitive and affective fields took a bigger part, it can be said that kinetically attainments are denser in Kosovo. Another fact is that the class hours of Physical Education and Sports are comparatively less than that of other courses. As a result; the fact that the program in Turkey includes more options and is more flexible provides advantages in generating solutions in regards to physical opportunities and material use, the inefficacy of class hours appears to be a disadvantage. On the other hand, kinetically attainments are limited due to the physical opportunities not being the same in all of the schools. In order to increase the mobility and applications of the courses in Turkey by paying attention to these specifications, prioritizing the physical opportunities for physical education and doing physical exercise, and increasing the amount of class hours can be suggested.
\end{abstract}

Keywords Turkey, Kosovo, Comparative Education, Physical Education and Sports

\section{Introduction}

Education has always been one of the emphasized subjects in our lives and societies throughout the years.
According to J. Dewey, "Education is not a preparation for life, instead it is the life itself; the purpose of education is not teaching the child what to think, but to think" [1]. Immanuel Kant stated that the most important source of the information the society has, is the education system. The comparison of education systems -of different countrieswhich affect and direct a society so fundamentally, gave way for the field of comparative education [2].

Türkoğlu describes comparative education as "a field of research which examines two or more education systems in different cultures and countries with their similarities and differences and in regards to their theoretical and practical aspects" [3].

According to Ergün, comparative education is "The comparison of the education systems applied in various societies, countries, areas and historic periods occasionally as a whole or through a few different aspects, in order to determine the common and different points, while also a science to benefit from in order to create a peaceful environment and soften the international relations in the theory and application of education, education policy, education planning and reforms" [4].

Comparison of Physical Education is not remote within the comparative education. The history of physical education is together with comparative education in the sense of a systematic and analytic study. The first significant data regarding the comparison of physical education and sports, were acquired by Leopold Berchtold and Auguste Basset in 1789, and Marc-Jullien in 1817 [5].

The main aims of physical education and sport in Turkey is that as a part of the general education, physical education plays an important role in the construction of the general education by means of ensuring the society to reach a healthy structure with regards to the body, spirit, mental and social aspects [6]. Physical education, in the general sense is a health and education activity which is effective and directly connected to the human health, character development, morale and productivity, strength and durableness in the national sense, the potential of high human strength, behavior and existence. In this regard, 
there is a full consensus concerning the fact that the individual and the society can be healthier, balanced, happy, long-living, successful and productive only in the case where the mental and intellectual development is suitable and balanced with the bodily development [7].

Ensuring the expansion and development of Physical Education and Sports within the scope and sense of amateurship, improving the application of the principle of Physical education and sports with appropriate internalization in the whole of the society, will improve the productivity levels of individuals from all segments, while also ensuring the protection of their physical and mental health, recreation of the young, middle-aged and old, working or not working, providing them with education, preventing them from becoming problematic individuals for the society, reintegrating the people who are in need of protection, disabled or guilty of crimes [8]. The aims of Physical Education and Sport in Kosovo include; the students learning their sportive talents and habits, adopting to the development of their movement abilities, learning to cooperate with people, the improvement of motional and functional abilities through individual and collective sport activities, improving the willpower and confidence of the individuals upon the performance of physical education and sports activities, constituting creativeness through various sports branches, living sports happily while improving the agility of the individual with recreation, physical education and competitions. Furthermore, it includes aims such as, acquiring information regarding cleanliness, habits concerned with holding the body straight, improving the endurance for tough situations and removing the laziness [9].

There is a curiosity for whether the Physical Education and Sports curriculum, which is very important in the general education, is enough in terms of weekly course hours, subject, content and attainments, raising children and the youth. For this purpose, there is a need for comparative education studies with different countries.

According to Hergüner, the purpose of comparative education studies concerned with Physical Education and Sports is to look through the framework of Physical Education and Sports while identifying the similarities and differences between the education systems of at least two or more countries. On the other hand, other aims can be listed as; revealing the strong and weak points of the current structure, attracting attention to questions and issues which raise curiosity, contributing to the increment of quality in Physical Education and Sports by making solution based suggestions depending on the result [10].

The Physical Education and Sports curriculums within the Education Systems in Turkey and Kosovo are compared in this study in the aspects of weekly course hours, subject, content and attainments. Both countries are evaluated in terms of education. The aim is to specify the similarities and differences between the curriculum in both countries, attracting attention to their positive and negative aspects while making suggestions in accordance with the results in order for the Physical education and sports lessons to be taught with relevance to the aim and contribute to the education.

\section{Method}

The descriptive method which is used mostly in comparative education studies, was also used in this study with the aim of determining the similarities and differences.

The purpose of this study is to comparatively examine and specify the similarities and differences between the curriculums in all grades of public primary, middle and high schools in Turkey and Kosovo, while also attracting attention to the positive and negative aspects of the education systems besides making suggestions in order to better the situation and contribute to the field.

\subsection{The Population of This Study}

Consists of the Education systems of Turkey and Kosovo which were randomly selected from the countries partaking in the Bologna process. The sampling includes the Physical Education and Sports curriculums, weekly course hours, subject, content and attainments of the course. In this sense, the public schools of Turkey and Kosovo are taken into consideration. The Physical Education and Sports curriculum and weekly course hours for a range of first grade and twelfth grade students published by the Head Council of Education and Morality of the Ministry of National Education in Turkey and the curriculum of Ministria e Arsimit e Shkencësdhe Teknologjisë Kosovë was taken as the base of the study. While the primary school statuses of both countries showed parallelism, differences were noted in middle and high schools. Namely; although there are many middle schools with different content (Regular middle school, Religious vocational middle school, etc.) and especially in high school (Girls' vocational school, Business high-school, Religious vocational high school, Anatolian high school, general school etc.), due to the fact that this variety does not exist in Kosovo, only the "regular middle school" and "general high school" curriculum and weekly course hours of the public schools were taken into consideration during the comparison.

\subsection{Data Collection Technique}

The "descriptive approach" which is one of the comparative education methods, was used in the study. On the other hand, techniques such as exposure, description, analyzing were used as well. Through the use of these techniques and approaches, the Physical education and sports curriculums in both countries were compared in terms of the similarities and differences between the content, subject, attainment, weekly course hours, and the comparison of the hours with other courses. In this study, the Physical education and sports curriculums and the weekly course schedules in both Turkey and Kosovo were examined. Within this scope, the data was collected with the help of the related theses, the regulations and internet pages of relative units of Ministries. 


\section{Findings}

\subsection{The Analysis of the Physical Education and Sports Course in Turkey}

Please note that the 2015-2016 academic year consists of 36 weeks. The calculations are made accordingly [11].

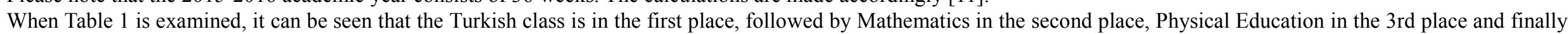

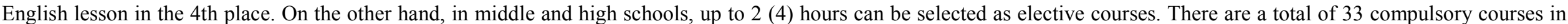

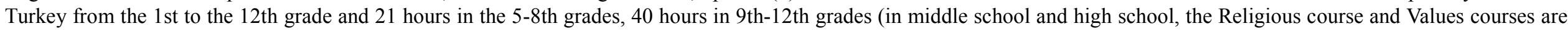

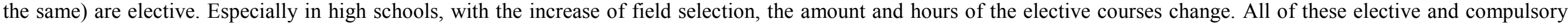
courses can change on the class and weekly class hour basis and some of them can be the same [12].

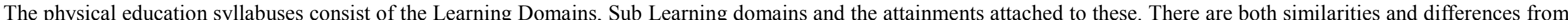

1 st grade to 12th grade. The Physical education and sports lesson consists of the three sections below.

Primary School (1-4th Grades) Games and Physical Activities Lesson [13].

Middle School (5-8th Grades) Physical Education and Sports Lesson [14].

High School (9-12th Grades) Physical Education and Sports Lesson [15].

In addition, in 5-8th grades, the elective Sport and Physical Activities course also exists [14].

Table 1. The comparison of the Physical Education and Sports course hours $(4+4+4)$ with certain courses within the curriculum $(4+4+4)$.

\begin{tabular}{|c|c|c|c|c|c|c|c|c|c|c|c|c|c|c|c|c|c|}
\hline & Courses & \multicolumn{12}{|c|}{ Annual class hours in compliance with grades $(4+4+4)$} & \multicolumn{4}{|c|}{ Annual Totals } \\
\hline & Courses & 1 & 2 & 3 & 4 & 5 & 6 & 7 & 8 & 9 & 10 & 11 & 12 & $\begin{array}{l}\text { Total } \\
\text { class } \\
\text { hours }\end{array}$ & $\begin{array}{l}\text { Primary } \\
\text { school total } \\
\text { class hours }\end{array}$ & $\begin{array}{c}\text { Middle } \\
\text { school } \\
\text { total } \\
\text { class } \\
\text { hours }\end{array}$ & $\begin{array}{c}\text { High } \\
\text { school } \\
\text { total } \\
\text { class } \\
\text { hours } \\
\end{array}$ \\
\hline 1 & Turkish & 360 & 360 & 288 & 288 & 216 & 216 & 180 & 180 & 180 & 180 & 180 & 180 & 2808 & 1296 & 792 & 720 \\
\hline 2 & Mathematics & 180 & 180 & 180 & 180 & 180 & 180 & 180 & 180 & 216 & 216 & - & - & 1872 & 720 & 720 & 432 \\
\hline 3 & $\begin{array}{l}\text { Physical education and } \\
\text { sport / Game and } \\
\text { physical activities }\end{array}$ & 180 & 180 & 180 & 72 & 72 & 72 & 72 & 72 & 72 & 72 & 72 & 72 & 1188 & 612 & 288 & 288 \\
\hline 4 & English & - & 72 & 72 & 72 & 108 & 108 & 144 & 144 & 108 & 72 & 72 & 72 & 1044 & 216 & 504 & 324 \\
\hline
\end{tabular}




\subsection{The Learning and Sub-Learning Context in the Physical Education and Sports Curriculum in Turkey, between 1st and 12th Grades}

Table 2. Contents of learning and sub-learning within the physical education and sports curriculum in Turkey

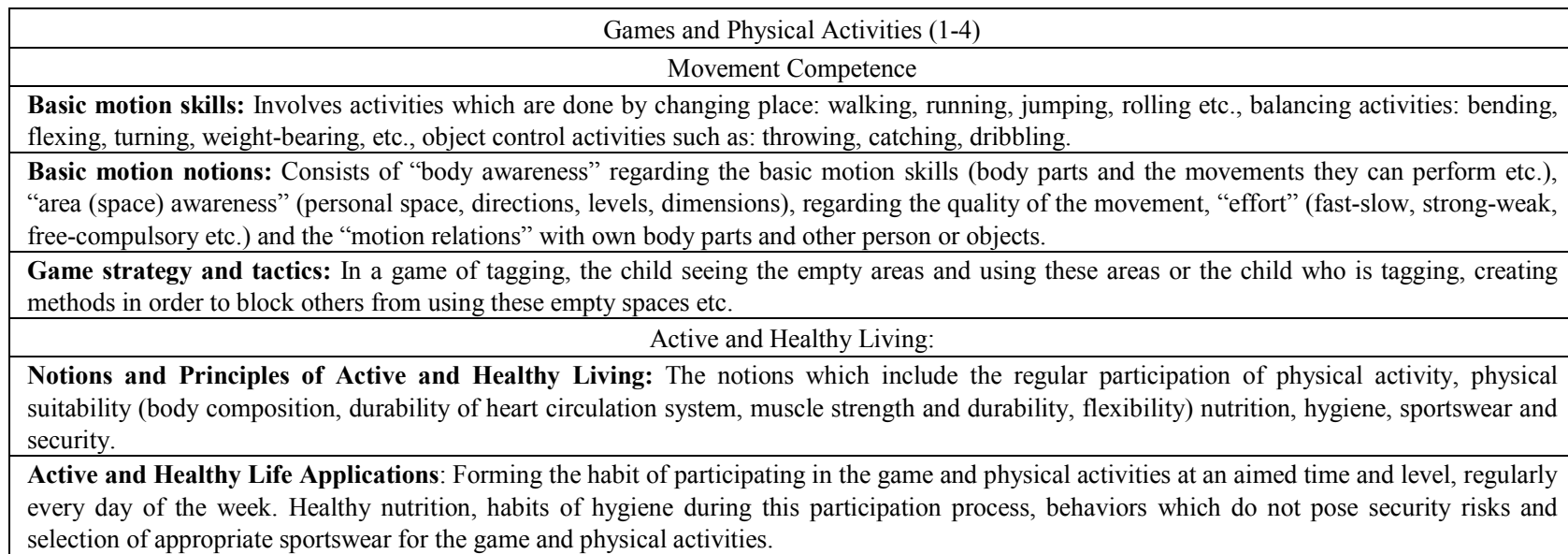
selection of appropriate sportswear for the game and physical activities.

\section{Our Cultural Experiences and Values:}

A. Recognizes and applies traditional games and dances of our culture and other cultures.

B. Participates in national holidays/certain day and weeks, willingly (Folk dances in April 23 National Sovereignty and Children's day, creative dances etc.)

Personal Skills: Self-knowledge, adaptation, management and coping skills, independent liability etc.

Thinking Skills: Observation, targeting, planning, applying, data processing, evaluation.

Social Skills: Communication skills, cooperation, fair-play, social responsibility, leadership etc. Game and Physical Activities (1st-4th Grades, 2015) [16].

\section{Physical Education and Sports (5-8)}

\section{Motion Competence}

Multilateral Motion Skills: Includes individual, team, racket and water sports, nature and adventure activities, dance activities etc. activities and sports, various activities and games that will prepare for sports, basic and combined motion skills (combination of changing location, balancing, and object control).

Motion Notions: Includes the classification of motion skills, productive motion principles (center of gravity, strength etc.), factors which affect the skill development.

Motion Strategy and Tactics: Tactics related to the games (attack and defense, net and racket, space/hack, aim) and tactics special to sports/activity.

\section{Active and Healthy Life}

Physical Activity: Includes physical suitability related to health and regular participation in activities.

Physical Activity Notion and Principles: Contains the personal, social and environmental effects, protection of health and conscious consumption.

Our Cultural Experiences and Values: Includes our traditional sports/games, the people who contribute to sports, athletes and the Olympics.

On the other hand, the basic skills related to life which should also contain motion competence and learning to live an active and healthy life are as follows:

Self-Management Skills: Organization, time management, self-knowledge etc.

Thinking Skills: Problem solving, learning to learn, thinking creatively and reflectively etc.

Social Skills: Social responsibility, respect for others and differences etc. [17].

Physical Education and Sports (9-12) Motion Knowledge and Skills: Besides cognitive and affective attainments, it rather includes psychomotor attainments. "Motion Knowledge and Skills" are divided into two sub learning categories; General Motion Knowledge and Skills, and Special Motion Knowledge and Skills.

General Motion Knowledge and Skills sub learning category is designed as a continuation of the basic and specialized information and skills learned in primary schools, and a field where motions that will form the base of sports are learned.

Special Motion Knowledge and Skills sub learning category is a field where motions related to the sports branches are acquired. Sportive skills are aimed to be taught through certain sports branches; however in this field, sport is considered as a vehicle rather than an aim in motion education.

Sport Culture and National Consciousness: In addition to psychomotor attainments, also cognitive and affective acquisitions are included. The Sport Culture and National Consciousness learning domain consists of the following sub learning domains; Personal Development and Healthy Living, Sport Consciousness and Organizations, Atatürk, National and Official Holidays.

While in the Personal Development and Healthy Living learning domain, the student transfers the information and skills attained in the education process to their daily life and these information and skills become their life style, the idea behind the Sport Consciousness and Organizations sub learning domain is to create the foundation of sport culture. In the Atatürk and National and Official Holidays sub learning domain, related Ataturkism subjects which are in the Journal of Head Council of Education and Morality, are presented [17]. 
Table 3. The Comparison of the Weekly Course Hours $(5+4+3(4))$ of Physical Education and Sports Lessons with certain Courses within the Curriculum.

\begin{tabular}{|c|c|c|c|c|c|c|c|c|c|c|c|c|c|c|c|c|c|c|}
\hline & Courses & \multicolumn{13}{|c|}{ Annual class hours in compliance with grades $(5+4+3(4))$} & \multicolumn{4}{|c|}{ Annual Totals } \\
\hline & Courses & 1 & 2 & 3 & 4 & 5 & 6 & 7 & 8 & 9 & 10 & 11 & 12 & 13 & $\begin{array}{l}\text { Total } \\
\text { class } \\
\text { hours }\end{array}$ & $\begin{array}{c}\text { Primary } \\
\text { school } \\
\text { total } \\
\text { class } \\
\text { hours } \\
\end{array}$ & $\begin{array}{c}\text { Middle } \\
\text { school } \\
\text { total } \\
\text { class } \\
\text { hours } \\
\end{array}$ & $\begin{array}{c}\text { High } \\
\text { school } \\
\text { total } \\
\text { class } \\
\text { hours } \\
\end{array}$ \\
\hline 1 & Arnavutça & 259 & 259 & 259 & 222 & 185 & 185 & 185 & 185 & 140 & 148 & 148 & 148 & 128 & 2451 & 1184 & 695 & 572 \\
\hline 2 & Matematik & 185 & 185 & 185 & 185 & 185 & 148 & 148 & 148 & 105 & 185 & 99 & 99 & 64 & 1921 & 925 & 549 & 447 \\
\hline 3 & $\begin{array}{l}\text { Physical } \\
\text { education } \\
\text { and sport }\end{array}$ & 74 & 74 & 74 & 74 & 74 & 74 & 74 & 74 & 70 & 74 & 74 & 66 & 64 & 940 & 370 & 292 & 278 \\
\hline 4 & English & & & 37 & 37 & 37 & 37 & 74 & 74 & 70 & 111 & 99 & 99 & 96 & 771 & 111 & 255 & 405 \\
\hline
\end{tabular}

Table 4. Contents of learning and sub-learning within the physical education and sports curriculum in Kosovo.

\begin{tabular}{|c|}
\hline $\begin{array}{l}\text { 1. Assessment and Evaluation: Applied general tests: Posture check, (A) - Body weight (BW), Body length (BL) etc. (M) }- \text { Standing long } \\
\text { jump, (SLJ), Standing high jump (SHJ), } 100 \text { meters Run, } 600 \mathrm{~m} \text { R - 800m R. and two tests regarding the learned techniques. Other tests can be } \\
\text { implemented in accordance with the school opportunities and/or teachers. The measurements being in primary school and are consolidated over } \\
\text { time. }\end{array}$ \\
\hline $\begin{array}{l}\text { 2. Natural motions, use of the equipment and games (main games, flag games): Walking, running, jumping, hurdle, crawling, hanging, } \\
\text { different types of carrying and supporting. Main games that are observed above for certain aims (developing motion, psychic, and functional } \\
\text { abilities). Densely applied in primary schools. Used less in middle and high schools. Main games based on walking, running, jumping, throwing, } \\
\text { climbing and carrying. Flag games with equipment. }\end{array}$ \\
\hline $\begin{array}{l}\text { 3. Athlethism: Learning the commands for stance and walking. Starting techniuqe for short distance running, controlled endurance run, exercises } \\
\text { regarding the improvement of the branches of flag, long, high and throwing. Hurdle and jogging } 8,10,12 \text { minutes. Distance run } 3000-4000 \mathrm{~m} \text {. } \\
\text { The technical cascading of the motions depend on the difficulty levels and certain motions are divided into different classifications. }\end{array}$ \\
\hline $\begin{array}{l}\text { 4. Gymnastics, rhythmic gymnastics and dance: Gymnastic games are played in the primary schools, gymnastic moves are divided into groups } \\
\text { depending on their level of difficulty and applied in the middle and high schools. Ground gymnastic/exercises-dance, jumps, pull-ups, parallell, } \\
\text { asymetric parallel, balance, circle, exercises or techniques on the equipment are applied through the end of the middle school. }\end{array}$ \\
\hline $\begin{array}{l}\text { 5. Team sports (Football, volleyball, handball, basketball): Learning the essential techniques and tactics, learning the special movement steps of } \\
\text { sports, technical and tactical practicing as team and individual, the technical and tacticals are divided into groups depending on the difficulty. }\end{array}$ \\
\hline $\begin{array}{l}\text { 6. Swimming: ( } 7-10 \text { days ). Getting used to the water. Learning the free (Kraul) swimming technique, backstroke, breaststroke and doplhin type } \\
\text { swimming- initiation and turns, according to rules; getting used to water is applied in primary and middle schools, swimming techniques in high } \\
\text { schools. }\end{array}$ \\
\hline $\begin{array}{l}\text { 7. Individual and martial arts: Martial arts: Wrestling, judo, karate: Main elements regarding self defense with semi active opponent. Tactical } \\
\text { elements regarding self defense with active opponent. }\end{array}$ \\
\hline $\begin{array}{l}\text { 8. Skiing and activities on snow: Promotion of skiing elements/apparatus, skiing in secured tracks, guidelines for walking with the skiing } \\
\text { equipment, skiing with wood/baton. }\end{array}$ \\
\hline 9. Picnics: At least two picnics per year, hiking in mountain regions. \\
\hline $\begin{array}{l}\text { 10. Sport theory: Apparent in high school classrooms. Learning what Physical education and sport is, learning the effects of sport movements on } \\
\text { the body, learning the features of sports etc. }\end{array}$ \\
\hline 11. Sport competitions: In at least two team sport branches, such as tennis, pingpong, karate etc. \\
\hline $\begin{array}{l}\text { 12. Adopted motions: Various strength games depending on the school opportunities, going out to the nature, competitions etc. Applied mostly in } \\
\text { primary schools as games. }\end{array}$ \\
\hline $\begin{array}{l}\text { Attainments: Being informed with the importance of bodily abilities, preparations for a healthy and modern life along with the relation of the } \\
\text { physical education with other subjects (language, music and mathematics). Relations with the mother tongue, nature knowledge, music and civics } \\
\text { education. Learning about the relation of the application techniques and course topics with other subjects. Learning the sportive values and main } \\
\text { sportive rules in the physical development of the student. Learning the benefits of water and nature, features and rules. The students learning to act } \\
\text { sportsmanlike while organizing competitions and applying the rules. Knowing the tactical and technical elements for self defence. Gaining agility, } \\
\text { improving intellectual ideas [9]. }\end{array}$ \\
\hline
\end{tabular}

\subsection{Analyses of the Physical Education and Sports Lessons in Kosovo}

When Table 3 is examined, there appears to be a total of 26 courses in the Kosovar curriculum between the 1st and 13 th grades. The density of the courses may vary throughout the years, however some courses may stay the same. Physical education and sports lesson takes up two hours per week and does not change through the course of 1 st to 13 th grades. (The classes in the last grades of middle and high schools in Kosovo finish earlier due to the necessary processes for graduation. This is the reason behind the difference seen in Table 3).

The Containment Percentage of Sports Branches in the Content of Physical Education and Sports Lessons in Kosovo

The physical education and sports in Kosovo consist of many sports activities and games. Anthropometric tests take place as part of the content of the Physical Education course in the beginning of the year (Height, weight, diameter and peripheral measurements) and bio motoric tests (capriole, 
running, coordination etc.) are evaluated. The content of the courses in the primary school generally consist of $50 \%$ games, $50 \%$ athletics and gymnastics. In the middle school however, the amount of games is decreased and the content is directed towards sport techniques. In the high school, sport theory is taught as an addition to techniques within the content.

Emphasized points: Anthropometric (height, weight etc.) bio motoric (durability, velocity, agility, coordination etc.) tests, athletics, gymnastics, swimming, picnics and sport competitions take place within the curriculum between the 1 st and 13th grades. The content of physical education and sport course in Kosovo consists of $20 \%$ athletics, $20 \%$ gymnastics, $26 \%$ collective sports and $13 \%$ individual sports. On the other hand, lessons in accordance with the current opportunities, theoretical lessons and natural movements in the value of $21 \%$ are included within the curriculum. Picnics, swimming and sport competitions are performed outside of the courses.

\subsection{Comparison of Physical Education and Sports Courses in Turkey and Kosovo}

The aim is to reveal at which points the physical education and sports curriculums of Turkey and Kosovo show similarities in order to create a model for the other part while also aiming to develop suggestions for eliminating the negative aspects and benefitting the reconstruction of the education. This study was conducted with the purpose of defining the similarities, differences, positive and negative aspects of the Physical Education and Sports Curriculums in Turkey and Kosovo. The Physical Education and Sports Curriculums within the general education systems in both countries were analyzed via the comparison and in terms of weekly course hours, subject content and attainments in the primary, middle and high school levels and the following similarities and differences with the positive and negative aspects were reached;

\subsubsection{The Similar Aspects of the Physical Education and Sports Curriculum in Turkey and Kosovo}

The Physical Education course ranked in the 3rd place when compared to Mathematics, English, Turkish and Albanian (In Kosovo) in both countries in terms of weekly course hours.

The learning domains and attainments of the physical education and sports curriculums are generally similar.

The concentration on games in the 1st, 2nd and 3rd grades in the primary school and individual and team sports in high schools, is similar. Similarly, many of the central administrations in Europe add basic motor activities such as walking, running, jumping and throwing, along with games into the educational curriculum for the first years of the primary-school education [18].

Physical Education course exists in every grade level in the primary, middle and high schools.

\subsubsection{The Different Aspects of the Physical Education and} Sports Curriculum in Turkey and Kosovo

The curriculum of the Physical education and sports course is prepared by the Education Ministry in Kosovo and distributed to the schools. This system exists also in other countries. For example in the USA (Indiana, Hawaii, Florida, California, Georgia, New Jersey, New York) the Physical Education curriculum is officially distributed to the schools by the government [19] In Turkey however, the learning, sub-learning and attainments of the curriculum, along with attainments and related activity examples are given. The physical education teachers benefit from these and create the plan and the activities themselves.

Anthropometric and Biometric tests are applied in the beginning of every year in Kosovo. In Turkey however, such application does not exist.

While the total amount of weekly course hours for Physical Education in Turkey throughout the 12 year education equals to 1188 hours, it equals to 940 hours in Kosovo in the end of the 13 year education. Namely, the amount of physical education course hours in Turkey is more than the course hours in Kosovo.

In Kosovo, the percentage of coverage in the learning domain and sports branches within the curriculum (amount of hours and percentile) are described. However, there is no such clarity in Turkey.

The names of the learning domains show similarities in every class grade in Kosovo (but the learning degree increases with every grade). On the other hand, in Turkey, even though the contents are similar, the learning and sub learning domains along with attainments, change throughout the primary, middle and high schools.

While the name of the course in Kosovo through the 1st and 13th grades is "Physical Education and Sport", in the case of Turkey, the course is named "Game and Physical Activities" in the grades 1-4. The name of the course is Physical Education and Sport in the middle and high schools.

While the Physical Education and Sport theory is given in the 10-13th grades in Kosovo, it begins in the 5th grade in Turkey.

There is no obligation regarding swimming in Turkey. Solely the schools which have the opportunity can add swimming into their curriculums. In Kosovo however, there are mandatory swimming lessons which take between 7-10 days. Moreover, picnics and competitions are not included within the curriculum in Turkey (picnics are organized via obtaining the necessary permissions, apart from the curriculum. Besides, there are also events such as interclass tournaments, county and city competitions).

As of curriculums, Turkey features more of cognitive and affective areas along with topics such as national and cultural values when compared to Kosovo. The Kosovar curriculum however features more of sports branches and subjects related to motion 
Table 5. The Features of the Physical Education and Sports Curriculum of Turkey and Kosovo

\begin{tabular}{|c|c|}
\hline Kosovo & Turkey \\
\hline $\begin{array}{l}\text { Positive Aspects } \\
\text { A. The Physical Education curriculum is provided by } \\
\text { the Ministry of Education every year. This } \\
\text { application can be considered as positive while } \\
\text { regarding the assurance of stability and equality in } \\
\text { education. } \\
\text { B. Branches such as athletics, gymnastics, football, } \\
\text { volleyball, handball, basketball, table tennis, } \\
\text { wrestling, judo, skiing, swimming, measurements } \\
\text { etc. are within the curriculum. } \\
\text { C. The necessary amount of teaching hours for each } \\
\text { learning domain and branch is pre-determined. } \\
\text { D. The practical and application parts of physical } \\
\text { education are emphasized. }\end{array}$ & $\begin{array}{l}\text { Positive Aspects } \\
\text { A. The contents of the curriculums are detailed, broad and rich. Based upon a } \\
\text { scientific foundation, and a modern curriculum. } \\
\text { B. The curriculums are flexible. This provides the physical education teachers with } \\
\text { the ability to create curriculums with regards to situations such as the geographical } \\
\text { conditions, opportunities of the school, the material status, level and readiness of } \\
\text { the students. } \\
\text { C. The cognitive and affective fields and topics such as culture of sports and national } \\
\text { values are given a wide coverage. } \\
\text { D. The learning stages in the curriculums vary in accordance with the age groups and } \\
\text { with varying levels of difficulty such as from easy to difficult or from basic to } \\
\text { complicate }\end{array}$ \\
\hline $\begin{array}{l}\text { Negative Aspects } \\
\text { A. There are mistakes in the learning cascades of the } \\
\text { techniques. For example, a technique which is } \\
\text { difficult to learn in gymnastics movements is given } \\
\text { in the 8th grade while a lighter technique is given in } \\
\text { the 9th grade. } \\
\text { B. There are mistakes in the sorting of the branches } \\
\text { within the curriculum. Skiing is in the curriculum } \\
\text { for the months of May and June, when there is no } \\
\text { snow. Swimming is seen prior to skiing, while the } \\
\text { weather is still cold. } \\
\text { C. The fact that the curriculum is not flexible may } \\
\text { cause issues that will result in not being able to } \\
\text { continue to carry out the lesson when special } \\
\text { situations or a deficiency of material occur. } \\
\text { D. A big portion of the curriculum is taken up by the } \\
\text { motional field, however the space given to } \\
\text { cognitive and affective fields is limited. }\end{array}$ & $\begin{array}{l}\text { Negative Aspects } \\
\text { A. Learning, sub-learning and attainments are given in great detail in the curriculum } \\
\text { (1-12th grades). However, there is no clarification regarding the topic or activities. } \\
\text { This situation may cause difficulties and complications in creating curriculums. } \\
\text { B. Motional and sport branch areas can be considered as not being given enough } \\
\text { place. This can be explained with insufficiency of facilities. } \\
\text { C. The amount of hours that will be spent for the learning domain or the sports branch } \\
\text { is not certain and this is causing vagueness. Generally the amount of class hours } \\
\text { within the curriculum are not enough for having a class that is appropriate for the } \\
\text { aim. In a previous study, the weekly class hours of physical education were deemed } \\
\text { to be insufficient in order to reach general and special aims [20] } \\
\text { D. There are no tests such as anthropometric or bio motoric tests within the curriculum } \\
\text { (These are important tests in terms of selecting talent, however the talented } \\
\text { students are generally elected through the natural observation method on the basis } \\
\text { of schools in Turkey. However the measurements/elections depending on tests are } \\
\text { being called into play within the scope of projects in the recent years by the sport } \\
\text { clubs). } \\
\text { E. The frequency of changing the curriculums can be stated as high. Although the } \\
\text { name of the institution is National Education, due to the constant changes in the } \\
\text { education system, it can be said that a long-term National education system is yet to } \\
\text { be settled. }\end{array}$ \\
\hline
\end{tabular}

\section{Results}

Upon the examination of the similarities, differences, positive and negative aspects of the physical education and sports curriculums in Turkey and Kosovo, the greatest difference could be stated as the fact that in Kosovo, the curriculum is prepared by the government and distributed to the schools while in Turkey the curriculum is left up to the teachers within a certain framework. In Kosovo, the curriculum is expected to be applied as identically as possible however the physical education teachers are given the permission to make changes to the curriculum in order to accord with the deficiency of material or saloons. This application ensures equal opportunities and stability for all of the children and youngsters in a country in terms of being taught the same subjects, to the same extent and within the same period of time while also being tested for the same topics. However this equality can be significant if it is provided also for sport facilities and materials. Giving the teachers the ability to act according to the situation is another positive aspect. However only giving certain topics and branches may cause other sport branches or cognitive and affective fields to be ignored and failure to develop.

Turkey is a country with a young population and many cultural and geographical differences; contains schools with very good and very bad opportunities. Therefore a monotype of a curriculum may be difficult to apply, because the opportunities of every school and city are not equal. Due to this fact, the content of the curriculums in Turkey is very rich, diverse and flexible.

The teachers are expected to create authentic curriculums through the activity examples in accordance with the learning, sub-learning and attainments. Namely, the curriculum is created with the decisions of UNESCO in mind while embracing the essential principles of the constructivist approach. The main purpose is to ensure every school to reach the aims which are expected to be reached with the attainments, using their own means and tools [17]. However Eraslan in their study where they compared the educational systems of Turkey and Finland emphasized that one of the reasons behind Finland's success in PISA was the standard education provided while the scholar also stated that decreasing the school type and curriculum variety in the basic educational level in Turkey to a minimum amount would pave the way for the students to receive a standard education similar with the children in Finland and the success difference between the children studying in diverse programs would be minimized [21]. 
The curriculum is quite flexible in Turkey. The sufficiency of our teachers and how they created the curriculums may be discussed. In addition, sometimes using different curriculums and assessment evaluation scales within the same county or even same school may disrupt the togetherness in education and some issues may arise due to different application and approaches of the teachers.

Another difference is that the Anthropometric and Bio motoric measurements conducted in Kosovo in the beginning of the year, are not practiced in Turkey.

The amount of class hours is higher in Turkey when compared to Kosovo (1188 in Turkey, 940 in Kosovo). On the other hand, when the total amount of class hours of the 1-12(13) grades are taken into consideration, the amount of courses in Turkey appear to be 33 (excluding the elective courses) while this number is 26 in Kosovo. Therefore, it can be said that the density of courses in Turkey is quite a bit more than Kosovo. While in some of the European countries, the class hours for the Physical Education course are set from a central administration similar with Turkey and Kosovo, in some other countries the decision is left to the schools. For example the class hours suggested for the first stage in the 2011/12 academic year in Ireland was 37 hours, in France the same value was 108 hours. While this value varied between 24-35 hours in Spain, Malta and Turkey in the second stage, it was between 102-108 hours in France and Austria [18].

In addition, besides the weekly physical education course hours in Turkey, "Elective Sport and Physical Activities Lesson" (Grades: 5-8) and a course which can be offered by willing teachers, "Extracurricular Exercise Activities" are also available. However the class hours for physical education and sports activities in both countries can be stated as insufficient. In the study of Eurydice, the amount of class hours specified for the physical education course are observed to be a short amount of time when compared with other courses and in the general scope of the European countries, while this indicates the lacking importance set for this course. [18].

The lack of supervision in the application of physical education curriculums $\left(12\left(13^{\text {th }}\right)\right.$ grades $)$ can be emphasized for both countries.

As a result in this study, the curriculums regarding the Physical education and sport in Turkey were observed to be more detailed, extensive, offering many options and flexible, however vague in terms of activities. The curriculum in Kosovo on the other hand, clearer, open, neat and less flexible. While in Turkey, cognitive and affective fields are given more places, the curriculum can be described as limited in the sense of motional terms / application, probably due to insufficiency of facilities. In Kosovo however, the conclusion is that the motional areas are denser but there are deficiencies in the cognitive and affective areas. Another observation is that the amount of Physical education course hours are higher than the amount in Kosovo in total, however both countries are observed to be in the 3rd rank while having less class hours when compared to Turkish-Albanian, Mathematics and English courses.

Upon the literature review regarding the comparative education in both countries, many studies are found in the field, however the insufficiency of studies in the field of Physical education and sports, stands out. Considering the benefits of comparative education, an increase in the comparative education studies within the field of Physical education and sports will surely contribute to the improvement of this field.

\section{Suggestions}

Anthropometric and Bio motoric tests may be applied in the Physical education and sports lesson in Turkey and the results may be evaluated in the talent selection. In accordance with the results, the curriculums may be readjusted in order to comply with the tendencies for sports branches on a regional basis to put more emphasis on certain sport branches, while creating youth setups, and possibly reaching higher levels of success as a candidate country for Olympics.

The Physical education (1-12th grades) curriculums may be prepared by the Ministry of National Education in a few different versions in accordance with different features of regions in terms of facilities and equipment. In this way, instead of every teacher or school attempting to adapt in accordance with their needs, a union can be formed under an alternative program presented by the ministry. On the other hand, building sport facilities (Saloon, field, court etc.) can be made obligatory as a precondition for the schooling projects.

The assessment and evaluation scales of the physical education and sports course in Turkey can be standardized in accordance with the curriculums.

Further assistance may be provided for schools which have needs in terms of sports facilities and equipment in Turkey.

Also the Physical education and sports curriculum in Kosovo could be prepared as a more flexible curriculum through the options presented from the central administration.

The weekly class hours of Physical education and sports may be increased in both countries. In this case, the physical education and sports education class hours in France, Austria, Portugal and Finland could be taken as examples.

In addition, studying the similar subjects in private and public schools in Turkey and some other developed countries (e.g. Germany, France, Finland) comparatively may be suggested.

A comparative education study may be conducted in other developed countries in terms of nurturing Physical education and sports educators.

As a continuation of this study, the Physical Education and Sport Colleges and Sports Faculties, the undergraduate 
and graduate programs of Physical Education and Sports Departments in universities of various countries may be studied in terms of curriculums and aptitude tests in a manner of comparative education.

\section{REFERENCES}

[1] Okçabol R. ÖğretmenYetiştirme Sistemimiz. ÜtopyaYayınevi. 2005:15.

[2] Turan K. Avrupa Birliğine Giriş Sürecinde Türk-Alman Eğitim Sistemlerinin Karşılaştırılarak Değerlendirilmesi. 2005. Available from: http://dhgm.meb.gov.tr/yayimlar/derg iler/Milli_Egitim_Dergisi/167/index3-turan.htm.

[3] Türkoğlu A. Türkiye ve Fransa'da Lise Programlarının Karş1laştırmalı Olarak İncelenmesi. 1984:18.

[4] Ergün M. Karşılaştırmalı Eğitim. Malatya: İnönü Üniversitesi, 1985.

[5] Harmandar D. Avrupa Birliğine Uyum Sürecinde Beden Eğitimi ve Spor Öğretmeni Yetiştirme Programlarının İncelenmesi: Türkiye-Belçika Karşılaştırması. Ankara: Gazi Üniversitesi 2010.

[6] Karaküçük S. Beden Eğitimi Öğretmenlerinin Faaliyet Alanları. In: Alanı GÜTE, editor. Abkara1991. p. 66.

[7] DPT. Devlet Planlama Teşkilatı; Beş Yıllık Kalkınma Planı. 5 ed. Ankara: Devlet Planlama Teşkilatı Yayını; 1983.

[8] İnal A. Beden Eğitimi ve Spor Bilimi. Nobel Akademik Yayıncilik. 2014:36.

[9] Edukata Fizike dhe Sportive In:Ministria e Arsimit Di, editor. Prishtinë: Ministria e arsimit shkencës dhe teknologjisë; 2015. Available from: http://masht.rks-gov.net/planet-1, http://masht.rks-gov.net/planet-2,

http://masht.rks-gov.net/planet-3,

http://masht.rks-gov.net/planet-4?page=3,

http://masht.rks-gov.net/planet-5? page $=3$,

http://masht.rks-gov.net/planet-6?

http://masht.rks-gov.net/planet-7?page=2,http://masht.rks-go v.net/planet-8? page $=2$,

http://masht.rks-gov.net/planet-9?page=4, http://masht.rksgov.net/planet-10,http://masht.rks-gov.net/planet-11?page=
3, http://masht.rks-gov.net/planet-12?page $=3$, http://masht.rk s-gov.net/planet-13?page $=2$.

[10] Hergüner G. Beden Eğitimi ve Sporda Karşılaştırmalı Eğitim. In: Sakarya Üniversitesi SBF, Öğretmenlik Bölümü, editor. 2016.

[11] 2015. Available from: http://ogm.meb.gov.tr/meb_iys_dosya lar/2015_05/22044001_calismatakvimi.pdf.

[12] MEB. T.C. Talim ve Terbiye Kurulu Başkanlığı Ders Çizelgeleri. 2015. Available from: http://ogm.meb.gov.tr/me b_iys_dosyalar/2015_05/22044001_calismatakvimi.pdf

[13] MEB T.C. Talimve Terbiye Kurulu Başkanlığı Ders Programları Oyun ve Fiziki Etkinlikler. 2012. Available from:http://ttkb.meb.gov.tr/www/ogretim-programlari/icerik 172 .

[14] MEB T.C. Talim ve Terbiye Kurulu Başkanlığı Ders Programları Ortaokul Beden Eğitimi (5-8). 2013. Available from:http://tkb.meb.gov.tr/www/ogretim-programlari/icerik $/ 72$.

[15] MEB T.C. Talim ve Terbiye Kurulu Başkanlığı Ders Programları Orta öğretim Programı Genel Liseler Beden Eğitimi 9-12. 2009. Available from: http://ttkb.meb.gov.tr/w ww/ogretimprogramlari/icerik/72.

[16] Oyun ve Fiziki Etkinlikler 1-4.sınıf, 9-12 öğretim programı. 2015.

[17] MEB T.C. Orta öğretim Genel Müdürlügü. 2015. Available from: 06100216 ilkogretimokullari_derscizelgeleri (7).rar RARarşiv, paketsizboyut 222.588 bayt.

[18] Avrupa'daki Okullarda Beden Eğitimi ve Spor [Internet]. european commission. 2013. Available from: http://eacea.ec.europa.eu/education/Eurydice/documents/the matic_reports/150TR_HI.pdf.

[19] Status of Physical Education in the USA In: Education NAfSaP, editor. 2010.

[20] Taşmektepligil Y, Yılmaz Ç, İmamoğlu O, Kılcıgil E. İlköğretim Okulların da Beden Eğitimi Ders Hedeflerinin Gerçekleşme Düzeyi. SPORMETRE Beden Eğitimi Ve Spor Bilimleri Dergisi. 2006; IV (4).

[21] Eraslan A. Finlandiya'nın PISA' daki Başarısının Nedenleri: Türkiye için Alınacak Dersler Necatibey Eğitim Fakültesi Elektronik Fen ve Matematik Eğitimi Dergisi (EFMED) 2009; 3(2):238-48. 